Ice was then applied, and full doses of opium administered, without any good result; and again failing to reduce the hernia by the taxis, aided by chloroform, I operated when the bowel had been strangulated ten hours, and eleven after its descent. I found the intestine deeply congested, its serous surface inflamed, but its tissues generally in good condition. The neck of the peritoneal sac was incised. Opium was freely administered, but he died twenty-one hours after the operation, from the collapse, which seems to result from the development of inflammatory effusion into the peritoneal cavity. The abdomen was examined after death, and peritonitis, with effused lymph, existed throughout the cavity. (Case vi.)

The next case differed somewhat in regard to its anatomical relations from the last described; for it was an instance of the "encysted hernia of the tunica vaginalis" of Sir Astley Cooper, but in its pathological conditions it resembled it very closely.

CASE. A middle aged man applied for admission at Guy's Hospital, suffering acutely with a hernial protrusion in the right side of the scrotum. He had been the subject of reducible hernia for six years. "The hernia fell down suddenly six years before under the influence of " a strain." On this occasion, the hernia had been down eight hours, and symptoms of strangulation had existed five hours. The usual means were employed, and chloroform administered before the application of the taxis, the only result of which was slightly to reduce the tension and size of the tumour. Therefore, I immediately operated, and found the small intestine of a deep claret colour, from congestion, but its tissues otherwise healthy. The neck of the peritoneal sac required to be incised before the bowel could be returned into the abdomen. Upon carefully examining the posterior wall of the sac I discovered a rent in it, through which the finger passed into the subserous connective tissue, and the contents of the sac would have been pushed behind the peritoneum if much force had been employed. This patient was treated with opium, and he made a good recovery without a single drawback. (Case 10.)

May we not conclude that the performance of an early operation saved the life of this man? Not a favourable point would have been gained by delay; but, on the contrary, I believe every morbid condition would have been aggravated. The anatomy of the parts, as revealed by the operation, also fully justified a proceeding which might by some be charged with precipitancy, for no manual dexterity would have ever returned the protrusion through the internal abdominal ring which admitted with difficulty quite the tip of my finger.

Time does not permit me to enter more fully into the details of the ten very interesting cases which have formed the data for these remarks; and I shall conclude by inviting the attention of the members to the following points as matters for discussion :-

1. The nature of this form of hernia, its anatornical relations, varieties, mode of development, and causes.

2 . Its frequency in proportion to other varieties of inguinal hernia.

3. The inutility of delay, or, it might be added, the culpabi. lity of not insisting upon an operation after the judicious application of the taxis has failed.

4. The facility with which the sac yields under pressure, demanding great care in the employment of the taxis.

5 . The advantages, in the after treatment, of opium in com. parison with other methods.

\section{EPIDEMIC SORE THROAT.}

By Charles Cowdeis., M.D., Physician to the County Hospital, Dorchester.

ThIs disease is exciting a deep interest in the medical profession, and the deepest anxiety and alarm in many a family, and, indeed, in some large districts throughout the land: it is the subject of not a few communications to our medical periodicals, and has been the theme of discussion at our medical societies. In a discussion on "A Case of Diphtheria", by Dr. Semple, recently brought before the Lundon Medical Society, that gentleman expressed his opinion, that " many different kinds" of sore throat were prevailing in the country, and all were receiving this appellation. If this be so, it is time that those who have had opportunities of witnessing epidemic sore throats, and especially where these have been of an aggravated and fatal character, should record their observation and experience on the matter.

It will be observed, that some of the following cases were registered as cases of "Diphtherite," and some of the cases now being watched by the writer have also been so considered; but, though he has his own decided opinion on the matter, he prefers that his paper should produce any impression it may, free from the prejudice which necessarily attaches to a new title, and he abstains, therefore, from employing any of the names in vogue, until the cases have been fairly reported and commented unon.

The first group of cases occurred about two years since, in which a lady, five of her children, and a nurse, were, within a fortnight, affected. 'The attack in each one was sudden; from being quite well overnight, a child would come down with its head slightly drawn on one side and held stiffly, the face pale, the tongue thickly furred, the firr being a dirtyish white at the back; the pulse quick and feeble; little or no increased heat of skin, except at night, when also some headache was complained of. On looking into the throat, one or more small yellowish white spots were to be seen on a swollen and red torsil. No great difficulty of swallowing was complained of. The yellowish white patches became rapidly larger in some of the cases, and in the lady herself, extended back to the pharynx and forward to the side of the tongue. In all seven, the attack was confined to the left tonsil and side of the throat. In a little child, little more than a year old, the thront was not af fected while the other seven were ill; but within a week of the recovery of the one last attacked, the tongue was affected with white patches round the sides at its anterior part; these left distinctly abraded spots: and in all the throats severely af fected, I have observed a similar appearance of loss of sub. stance. In none of these cases was there any rash.

The second group of cases occurred at Wynford Eagle, about eleven miles from this place. I was called to see in consultation a woman who was affected with sore throat. I learned from the medical friend whom I met, that sore throats had been very prevalent there, attacking a large proportion of the children living in three blocks of cottages, and that some of these had very rapidly died of the disease. Our patient had been similarly attacked, but was now suffering from the addition of a large abscess in one of the tonsils. I visited all the cottages, and saw all who were suffering from the throat affection. The throats presented precisely similar appearances as in the cases of the first group, and, as in them, the patients were void of rash; except that one child was said to have had some blotches occasionally visible, but not persistent. In one of these cases there was renal dropsy.

The third group of cases I saw in the parish of Holwell, fourteen miles hence, in a gentleman's house standing away from the village. His wife, brother, and a child were all seized within ten days with sore throats of precisely similar character to that first described. In the lady, there was also an abscess of one tonsil.

The fourth group of cases, though not perhaps quite properly placed in this order, is so put to keep the chronology of the series unbroken. But there were three cases of sore throat, in which the appearance of the tongue and throat, and the almost entire absence of day-fever, closely resembled the same characteristics of the cases above described; and therefore, although they occurred in a family of which several members were ill of scarlet fever, it has been deemed advisable to record them here. They occurred at West Chelborough, Dorset, in August 1857 ; and it will be subsequently seen that in that district an extensive epidemic of scarlatina and sore throat appeared to take its commencement in these cases; for scarlatina and cases of sore throat-some of which were registered as cases of diphtheritebecame very prevalent thereabouts, spreading from Chelborough and Corscomb to Evershot and adjacent parishes. So extensively did this epidemic prevail, that the district surgeon had within eight montbs three hundred and forty-six cases, - a large proportion of the population.

The fifth group of cases which came under my observation, was in the above-mentioned district, in the parish of Rampisham, and the reader's careful attention is requested at this point. A gentleman of this parish brought to me two little girls suffering from sore throat. Their tonsils were covered with small patches of yellowish-white exudation on swollen and red tonsils; in the elder girl similar patches of exudation were to be seen on the back of the pharynx. These children both recovered. A little brother was tuken ill, and sank in two days: I did not see him. The mother, who had been absent, returned while this little boy was ill, and a few days after she was attacked, and also sunk after a very short illness: I was not summoned to her till she was in articulo mortis. In her throat there was less appearance of exudation or abrasion than in most. When I saw her six hours before death, she swal- 
lowed repeatedly without difficulty, but her breathing was very laboured; she appeared to be dying of depression of vital power and exhaustion (asthenia). The governess and nurse also had had sore throats. The last child affected had coryza, enlarged tonsils and difficult breathing, and died in about four days. In none of these cases was there any rash. The lady's case had been pronounced to be diphtherite.

I made repeated inquiry about these cases, and as to communication between the house at Rampisham and neighbouring places where scarlatina prevailed, and was repeatedly assured that there was no evidence to be found of any such communication. Some time afterwards I obtained information which induced me to renew my inquiry on this point, and I transcribe the note of the medical gentleman who attended the case about to be alluderl to: he says,-

"Fmma Johnson came, Sept. 1 sth, from Yeovil to Evershot; I attended her the day after with sore throat (no eruption). She returned home in six days.

"Sept. 25. Four of the children of her sister, at Evershot, with whom she had been staying, were taken with sore throat and the eruption of scarlatina. The next day six more cases oecurred in another part of the same house, occupied by a different family, all with sore throat and eruption.

"Eliza Frampton came to attend upon these children, and, two days after, was taken with sore throat without eruption. Her younger sister, Charlotte Lewis, came to see her, and was attacked with sore throat without eruption.

"Charlotte Lewis, before recovery from this sore throat, went to the house of the gentleman at Rampisham to assist as a servant, and was shortly after engaged in nursing the children; but she was soon sent home as too ill to work. I was sent for to see her, and the first thing shown to me was her bloody urine. She, however, returned to the service of the gentleman at Rampisham before she had recovered either from her sore throat or renal affection. The lady of the house and one child had died of sore throat before I ceased to attend this woman in their house."

She returned to them October 21st, and the two first cases of group five were brought to me October 26 th.*

The sixth group is a numerous one, now under observation in the same parish as the preceding-Rampisham. After an interval of a year, epidemic sore throat reappeared last month. It is prevalent in many families, and already there have been eight denths-all of children. I have visited the surviving cases with the medical officer of the district, and the throats present the same character as in the cases already detailed, viz. patches of exudation, in some extending over the back of the pharynx; in some, accompanied by abscess of the tonsil; in a few, followed by renal dropsy; but in none accompanied by rash.

There is constant communication between this parish and the adjoining one of Evershot, where, just as last year, scarlatina is still extensively prevailing. I have accompanied my medical friend through this parish of Evershot, and have examined his cases, some with throat-affection without rash, and some with it. He informs me that in some of his cases where there has been no rash, peeling of the skin has taken placecase of which kind we shall presently allude to in another group. In one family at Evershot, a lad of fifteen had had a severe sore throat without rash; in a younger brother there were sore throat and rash followed by albuminuria; in another. sore throat, rash, and abscess of tonsils; in a fourth, sore throat and rash. All these were severe cases; and my friend thinks that but for their dwelling close to his garden, and so being supplied with food as well as physic from his house, some of these must inevitally have sunk. This gentleman has, as already mentioned, within the year, attended from three hun. dred aml sixty to four hundred cases; and he informs me, that he registered some cases as diphtherite, but afterwards altered his opinion about them when he found in the same family cases subsequently presenting the character of normal scarlet fever.

The seventh group is a small one, still under observation in our County Hospital. Except two cases, occurring in the family of a respectable tradesman in August last, I had only seen an occasional case or two in this place for more than a year, till last month (October).

* Since writing the above, I have ascertained that another servant in the same family had been in constant communication with patients ill of searlatina, in september. She had a sore throat when she entered the family. September i2nd. She subsequently had bloody urine, and her skin peeled and she lins eser smce hat albuminuria and anasarca. 'This information has been supulied by her medical attendant.
During a short absence from home in September, one of my patients in the hospital (a case of chorea) was attacked with scarlatina and died. Subsequently, a nu'se of one of the female wards was attacked with sore throat. She afterwards had albuminuria, and her skin peeled off; but till these sequeln stamped the case, it had not been regarded as one of scarlatina. She was sent away. Her successor, nine days after she took possession of her room, was affected with sore throat, but not severely. Three days afterwards, three female patients, occupying the same ward, were, within twelve hours of each other, attacked with sore throat. They presented the patches of exudation, and other characters, just as before described.**

Before proceeding to comment upon these cases, may I bo permitted to add, though lengthening my paper, that, among my out-patients some time since, there came a young woman with severe renal dropsy, who had just been nursing a brother's children ill of scarlatina. She had had the disease many years before; she now had "a dreadful sore throat," but no eruption, followed by renal dropsy. Other cases of sore throat in adults, while attending on cases of scarlatina, have been reported to me-but enough.

Microscopic examination revealed a mass of cellular matter; the cells, where separated, were seen to be nucleated: the nuclei and margins of the cells becoming more clearly defined on the addition of acetic acid. I could not discern any lifference between the best defined cells and the drawing of $p u s$ cells treated with acetic acid, as figured in Paget's Surgical Pathology, vol. $\mathrm{i}$, with which I carefully compared them. No epithelium-no connective tissue fibres could be seen.

[To be continued.]

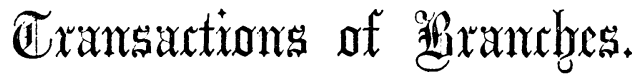

\section{BIRMINGHAM AND MIDLAND COUNTIES BRANCH.}

ON INFANTILE LIENTERY.

By WillorjanizY F. WADE, B.A., M.B., Physician to the General Dispensary, formerly Resident Physician to the General Hospital, Birmingham.

[Read October 14th.]

A DISEASE has been recognised and described by all systematic medical writers, from the earliest times till the last few years, under the name of "leientery" or "lientery", "lei-" or "lienteria", " diarrhœa lei-" or "li-enterica", "lævitas", or "levitas intestinorum", etc.-terms all derived from the one root, the Greek $\lambda \in \hat{i o s}$, lavis, "smooth"; and, from this circumstance, I cannot help thinking that to the Greeks, who invented and used the term $\lambda \epsilon \epsilon \in \nu \tau \in \rho^{\prime} \alpha$, it represented a theory, viz., that the intestines were abnormally smooth, and were unable, on that account, to delay the passage of the food; and that, consequently, it lapsed or glided through undigested. This latter feature of the disease it is by which it is characterised, as may be seen from the following description by Saurages (Nosologia Methodica, etc., auct. Fr. Boissier de Sauvages. Amsteludami : $17(33.8 \mathrm{vo}$ ), which also concords with those of other writers:"Alimenta parum aux vix mutata per alvum dejiciuntur et sinul station a deglutione vel parvâ interpositâ morâ dejectio excitatur" (vol. v, p. 145); or, as it may be rendered: "Food is hurried through the bowels with little or no change in its condition, and a call to stool immediately or almost immediately follows its ingestion."

Taken in connexion with the derivation, it is a curious fact that, in the only three post mortem examinations which I have been alle to perform on the subjects of this disorder (and in them it was not uncomplicated), the small intestines were thin, pale, and the mucous membrane smooth and attenuated, the valvulæ conniventes almost entirely obliterated.

Of late years, however, lientery has been degraded from the position of a substantive disease, which it used to occupy, into that of an occasional or accidental symptom of the other forms of bowel complaint, or of infantile dyspepsia; and, having been thus rendered apparently unimportant, it has come to be neglected, then overlooked, and finally forgotten.

* A fourth has, since writing the above, been attrcked in a precisely similar manner; she was in the ward in which my patient was seized with sca latina and died in September last. 